Olga Karkishchenko

Lomonosov Moscow State University

Moscow, Russia

to_oliya@rambler.ru

\title{
ANGLO-NORMAN BORROWINGS IN IRISH
}

\section{0 . Introduction}

In this contribution I will report on the results of my analysis of a portion of the Irish vocabulary that dates back to the period of the Norman Conquest. For the purposes of this paper, I will primarily focus on reviewing the state of scholarship dedicated to the Anglo-Norman borrowings in Irish. I will also present a general overview and the loanword system classification based upon a set of Anglo-Norman lexemes. Parallels between Middle Irish and Middle English lexical data will also be drawn.

We shall start with an introduction to the general picture of the cultural and language contact of the time. Following the introduction, we shall deal with the peculiarities of the Anglo-Norman dialect of French and its reflections in Irish. We will then proceed to the phonetic form of the AngloNorman borrowings and deal with the major changes they underwent. Then we will turn our attention to the semantics of the borrowed vocabulary and the way it was preserved in the modern language. The final problem under discussion will be the one of dating the loanwords and for instances where possible, a rough two-period classification will be introduced and developed.

1. The question of language interaction and linguistic borrowing in Irish

According to a popular definition, any element of a foreign language transferred to another through the mechanism of the language interaction is qualified as a borrowing (LED: 158-159). Of all the language elements the words (or the lexemes) are the most often adopted ones. While adapting into the new language, they often undergo considerable changes in their form and semantics which mainly applies to the cases of early borrowings that become fully integrated into the language. Later borrowings, however, more often preserve their form and are more easily classified. As a rule, 
they represent well structured word groups characterised by a clear-cut semantic affiliation to a certain special domain of human activity. Their semantic acquisition depends on the fact whether a word with a close meaning existed in the recipient language. Anglo-Norman loanwords perfectly illustrate the case.

In the course of the Irish language history Latin, French and English were the main sources of the loanwords, though there were also few others. Several words were borrowed from the continental Celtic languages (with their origins still disputable) as well as a considerable bulk of loanwords shifted into Irish from the autochthonous pre-Indo-European protolanguages (Kalygin \& Korolyov 2006: 161). A few dozen of Scandinavian loanwords are also present since the tenth century, which clearly fall into a number of semantic categories (SnG: 333).

The French language was prominent in the towns and the fortified castles of Ireland in the twelfth century, but was already giving its way to English as the language of everyday communication by the thirteenth century, although it continued to be used on a formal level for another hundred years. The strong influence of the Anglo-Norman dialect of French in this period caused an active borrowing of French vocabulary into Irish. The Anglo-Norman dialect was the language of French noblemen and clergy, thus the area of its application was obviously marked. The French colonies in Ireland had never been of any significant number and by the end of the thirteenth century, despite numerous attempts of the English government to prevent the integration of the French into the Irish society, the French had been fully assimilated. The influence of the new governors on the language proved to be strong in certain areas, but obtained quite a short-term effect (SnG: 439-440). The penetration of the French lexis into Irish started in the end of the Middle Irish period, but for most of the words the first written fixation only took place not until the late thirteenth century. It is important to note that the Irish language documents of this period on the whole are rare (Kalygin \& Korolyov 2006: 178-180).

\section{Anglo-Norman dialect in Ireland and Britain: Phonetic issues}

The Anglo-Normans who invaded Britain and Ireland were clear representatives of the French culture, the language and of the French feudal state structure. Most of them used Northern or North-Western dialects of French. The Anglo-Norman dialect was formed a few years after the conquest of Britain and dominated the country for more than three hundred years greatly influencing the development of the English language (Baugh 
1935: 174-176). Until the fourteenth century A-N was not only the language of the noblemen but also the language of the literature of the colonists. We can refer to the poems of The Song of Dermot and the Earl, and The Walling of New Ross, dated to the late thirteenth century, and probably composed in Waterford, and a number of administrative and legal texts created in Ireland that have been preserved to this day and serve as examples of the Anglo-Norman prose (Ó Corráin n.d.).

The peculiarities of the Anglo-Norman dialect that are also common for northern or north-western dialects of French and that distinguish it from the central dialect of Paris had mainly to do with phonetics (Brunner 2003: 136-137). Among them are the retaining of velar articulation of $[\mathrm{k}]$ and $[\mathrm{g}]$ followed by [a], while the corresponding sounds in the central dialect would be [t $\mathrm{t}]$ and [dž]: MI cabún (< AN capun OF chapon), MI galún (< AN galun OF jalon). The initial [w] in words of Germanic origin was also retained in contrast to $[\mathrm{g}]$ of the central dialect: MI baránta (< AN warantie $\sim$ OF guarantie), MI bárda (< AN warde $\sim$ OF guarde). The last syllable of the word used to be stressed except for the words ending in - $e$ (Risk 1970-1971: 590; Baugh 1935: 175-176). At the start of the twelfth century, the differences were insignificant, but as the Englishmen and the Irishmen using French tried to adjust the sounds to the habitual articulation patterns and therefore substituted the unusual phonemes with the more familiar ones, the phonetic peculiarities characterising the continental French language were gradually eliminated. These changes were reflected in the form of the French loanwords in both Irish and English. Thus, in the language that was introduced in Ireland in the twelfth century northern traits were predominant.

Most of the borrowings, as mentioned previously, have analogous correspondences in Middle English, this fact obscuring their origin: it is not clear whether they have been borrowed directly from Anglo-Norman or brought into Irish by means of English. Here the phonetic form of the word can be of help in defining the source language, as a number of distinctive features can be found in both types of borrowed words. Phonetic analysis of the borrowings can sometimes provide a solid ground for their chronological classification and dating. The most detailed analysis of the typical phonetic word forms that entered the language under the Norman Conquest has been carried out by Henry Risk $(1970-71 ; 1974)$ in his "French LoanWords in Irish". It is not my intention to go very deeply into phonetic details here, and I will only advance the four basic principles that seemed to govern the adaptation of Anglo-Norman words borrowed directly into the Irish language (Risk 1970-1971: 591-595): 
1. Vowels in stressed syllables in Anglo-Norman give long vowels in Irish: bataille > batáille, castel > castél, cofre > cófra

2. Vowels in syllables with secondary stress (the initial syllable of a polysyllabic word) in Anglo-Norman give short vowels in Irish: milliun > milliún, ospitel $>$ ospidél, paroche $>$ paróiste

3. Consonants in contact with front vowels in Anglo-Norman give palatal consonants in Irish: chapele > saipél, abis > aibís, habit > aibit

4. Consonants in contact with back vowels in Anglo-Norman give non-palatal consonants in Irish.

It can be seen that the most important role is given to the opposition between short vs. long and stressed vs. unstressed vowels that may facilitate classification of certain words and resolve the issue of their dating. What is more important, one can differentiate a direct borrowing from the one previously assimilated by the English language (which is not to be regarded as a pure Anglo-Norman borrowing). To illustrate the idea I suggest turning to several examples. Before occuring in Irish, these words underwent the influence of English. In the examples below, they are juxtaposed with the possible forms that a direct borrowing could have developed:

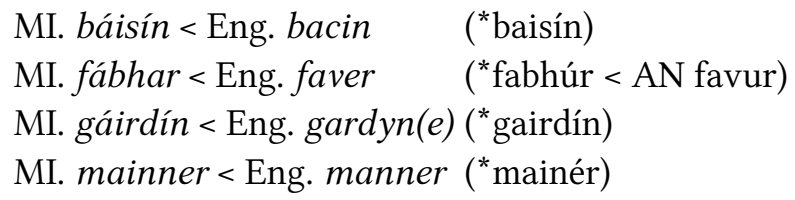

The list outlined above is certainly not exhaustive and there are many other examples that need to be considered for a comprehensive study. A lot can be said here about regional variation in pronunciation and the form of the borrowed words. Modern dictionaries suggest up to nine different options, varying in vowel representation and length as well as the quality of the consonants and their combinations. This also presents an interesting topic for research, not to mention the self-suggesting question of how the French accentuation patterns influenced those of the Munster dialect.

\section{Anglo-Norman borrowings: Semantic issues}

Semantics of the borrowed vocabulary shows what spheres of life in society underwent the most considerable influence from the invaders (ibid., 586-590). The words belong mostly to the specialised language and serve to name the ideas and objects not typical or new to the Irish soci- 
ety before the Norman invasion. As the interaction of cultures and languages was a lot more intense in Britain and had a very different character, a much greater amount of French words entered the English language. However, both Irish and English primarily adopted such words that pertained to the new ideas and objects that were borrowed from the Normans by these two (at that stage, perceived as "inferior") cultures. A number of significant and relatively homogeneous semantic groups of borrowings can be drawn together:

State governing and territorial division (ranks, titles, terms of territorial division): oifistél < offic(i)el, méra < mere, tresurér/treisinéir < tresorer; cunntaois < cuntesse, biocúnt/biocunt < vicunte, buirgéis < burgeis.

Legislative and legal terminology (general terms, law proceedings and their participants, penalties, ownership terms): giustís < justis, sísa < sise, turnae < aturne, baránta/barántas < warantie/warrants, prisún < prison, eighir < heire.

Architectural and construction terms: áirse < arche, caistéal < castel, túr < tur, coirbél < corbel, cúinne < cuing, casúr < cassur.

Military terms (military units, troops, ordnance and ammunition): trúp $(a)<\operatorname{trup}(e)$, bárda < warde, leith-tenónt < leutenaunt, seirsénach $<$ sergent, glaeidhe < gladie, halabard < hal(le)bard.

Religion and clergy: cardináil < cardinal, caibeallán < capelain, preiciúr/preitsiúr < prechur, paróiste < paroche, seipéal < chapelle, scrioptúir < scripture.

More than $50 \%$ of the loanwords refer to different spheres of everyday life and it becomes clear from their meaning that they could only be used by the nobility. They have to do with:

Fashion and style: aibít < (h)abit, cóta < cote, gúna < gune, coiléar < coler, mála < male, pérla < perle, asmirón < asmerant,

Cooking and food: dinéar < dinner, bangcéd < banquet, plúr < flur, uinniún < oignun, finéagra < vinegre, buidél < botel,

Interior of the house: seómra < chaum(b)re, soilér < celer, cófra < cofre, seiminér < cheminel, cúilt < cuilte, spúinse < sponge.

Many of the everyday words don't comply with any classifications: doctúir < doctor, bagáiste < baggage, bésta < beste, córda < corde.

Among them one can encounter quite a few abstract notions:

buntáiste < avauntage, damáiste < damage. 
Along with the groups mentioned above a considerable amount of personal Christian names was borrowed and integrated into the language and became widespread:

Seaán/Seoán < Johan, Séamus < Jemes, Máire < Mari(e), Síle < $(\mathrm{Ce})$ cile, Sinéad < fennet, Siobhán < foanne.

Family names also reflect the history of the invasion. It is common knowledge that the patronymic prefix "Fitz-" (which is an actual Irish pattern of the name formation) was derived from the French word "fils"; as well as numerous surnames starting with "De" leave no doubts about their origin:

Fitzpatrick, Fitzroy, Fitzhugh; De Burca, De Brún, De Paor.

One could add the surname "Devereaux" which is still commonly pronounced [dever' ex] in County Wexford. Distinct parallels with English can also be traced in most cases.

However, it is intriguing to compare different roles that the loanwords play in both languages. It is known that the borrowing into English was so intense and abundant on all the levels of the language, that it caused not only a general reconstruction of English vocabulary, but also strongly affected its system of the word formation (Baugh 1935: 167; Smirnitsky 1998: 31-36). The influence on the Irish language was far less convincing. In this case one can hardly speak of any "reconstruction" of the vocabulary and that can be explained by what was a comparatively short cultural interaction with the Normans, their quick assimilation as well as the strong position that Irish enjoyed at that period. This means that the borrowings were limited to the vocabulary, while the typical Irish word formation patterns were not affected. Examples of the opposite are very few and insignificant, but are, however, important to look at. For instance, a productive agent suffix -éir/-óir (<-er/-eur) was borrowed and assimilated, enlarging the set of already existing ones: the Irish -aí and the Latin -aire (<-arius). The new affix constituted an intrinsic element of many of the borrowed nouns and was later interpreted as a separate morpheme, which started to be used with French, Irish and international vocabulary: cúirtéir, óstóir; múinteoir, breathnóir, baincéir.

A detailed analysis of modern Irish texts and dictionaries shows that though the greatest part of the borrowed lexis was preserved in the language it rarely entered any common use. Naturally, having a narrow and specialised meaning from the start most of them became obsolete together with the notions they gave name to and are now referred to as historicisms. Though sometimes this led to a secondary borrowing of some 
kind of a "special" word, this time from English: leifteanant $<$ En. lieutenant (earlier: leith-tenónt < AN leutenaunt); sáirsint < En. sergeant (earlier: seirsénach < AN sergent); patraisc < En. partridge (earlier: pertrís < AN perdriz). But even some of the more colloquial words that were bold enough to have made their way into the language could not compete with the vernacular; quite often the Irish word would oust the newcomer: asúir (azur) > gormghlas; bangcéd (banquet) > flea; bhilaiste (village) > sráidbhaile; cuncúr (cunquerur) > buaiteoir, gabhálaí; coráiste (corage) > misneach, uchtach; currúra (currure) > teachtaire, giolla, turais. Unlike the situation in the English language, Irish did not allow any borrowed words that were in some way assimilated to become a centre of already existing semantic groups; they used to remain at the periphery and are now perceived as stylistically marked. This conclusion is based on a comparison of the dictionary data, word frequency and the collocability of the words. We can look at several examples:

$\begin{array}{lll}\text { Anglo-Norman } & \text { Irish } & \text { English } \\ \text { aventure } & \text { eachtra, fiontar, amhantar } & \text { adventure, incident } \\ \text { fortune } & \text { cinniúint, ádh, fortún } & \text { fortune, luck, destiny } \\ \text { beste } & \text { ainmhí, beithíoch, béist } & \text { animal, beast, brute } \\ \text { chaunge } & \text { athrú, malartú, sóinseáil } & \text { change, modification, alteration }\end{array}$

Thus, it may be proved that if a French word of a common meaning enters a language it joins a certain synonymic group formed by an already existing word and its semantic differentiation has to be studied in each separate case. The reasoning within certain semantic groups may go as follows. As soon as the architecture, the military and the economic sectors were underdeveloped in Ireland at the time of the Norman Conquest in comparison to the French system, there could have been no competition between the native vocabulary and that of the invaders. The legal and religious traditions were however very strong and complex which implied that any special vocabulary they employed was very rich. It was pushed aside by French words only because of the new legal and religious institutions that were being established during that period. However, in spite of the intrusion of the French terms Irish managed to keep some of the vernacular words in the active usage, though Anglo-Norman equivalents were initially borrowed and recorded: ceart - MI giustís, suí - MI sísa, achainí - MI siúit, persún (En. parson) - sagart - ministir. Despite some semantic controversies, the borrowed French vocabulary was morphologically well assimilated into the Irish language: i.e. words naturally distributed into declensions and became productive sources for word formation 
with the help of Irish affixes. Modern Irish dictionaries provide numerous examples of Anglo-Norman loanwords forming different parts of speech. Thus, the instances of the borrowings that still exist have at least formally become a natural part of the modern lexis.

\section{Anglo-Norman borrowings: Question of dating}

In dating the borrowings the information is drawn from the documents and pieces of creative writing produced during the first two centuries following the Norman Conquest, or other sources such as the Annals, The Book of Leinster, Irish Grammatical Tracts, etc. (SnG: 224). There are various methods to date the borrowings, but the most reliable one seems to be that of phonetic analysis, especially when the date of the earliest written attestation of the word cannot be easily determined. On the other hand, some phonetic forms cannot be devoid of ambiguous interpretation on the basis of data provided by their source language. In the last instance, the question of dating is extremely important in order to define whether the word was a direct borrowing or entered the language through the medium of English. The dating of the loanwords is nevertheless always problematic. The only reliable indication is the date of the first written record, which however does not inform us how long the word had existed in the language before it was first written down. We can refer to the most obvious examples of the words that clearly underwent some morphological and phonetic changes: cartún < quarterun, spéis < peis (Risk 1970-1971: 628); dissimilation: coilér < quarrer; haplology: cuncúr < cunquerur; popular etymology: leith-tenónt < AN leutenaunt.

Some of the Anglo-Norman loanwords were written down as soon as they were borrowed and can therefore be easily dated. Others, however, only existed in spoken language and the only way to identify them as Anglo-Norman loanwords is by their form and appropriate semantics. Here parallels with borrowings into English can be of help, especially if in English the word can be dated with a certain degree of accuracy.

However uncertain any of the proposed datings may be, we can try to classify the whole bulk of borrowings and determine the periods when they most likely appeared in the language by concentrating on their historical background. It would be appropriate to presume that the greater part of the loanwords was adopted when French was at its strongest - during the first 150-200 years after the Conquest (Kalygin \& Korolyov 2006: 178). Thus, the words registered within this period are likely to represent the oldest layer of the borrowings. The early fourteenth century is 
characterised by a noticeable decline of the French language influence. So, one might take the introduction to the Kilkenny Statutes as the borderline between these two periods in Ireland and consider the two groups of loanwords to see if they have any particular distinguishing characteristics.

The first period obviously shows a lesser amount of written down words, which is also true for the English language according to Albert Baugh's semantic classification (Baugh 1935: 168): AN castel > MI castél (1189) / ME castel (1075); AN barun > MI barún (1261) / ME baron (1200), AN prisun $>$ MI prisún (1267) / ME prisune (1123). ${ }^{1}$ They constitute one third of the set of 100 words that I selected for analysis. One can say that they have certain features in common, though it is hard to draw a distinct line between the two periods both phonetically and semantically. Interestingly enough, the orthography of most loanwords that I refer in the first period does not follow the caol le caol, leathan le leathan rule, which was introduced in the middle of the fourteenth century coinciding with the time that I suggested as an approximate border line : bésta, cardináil, giustís (iustís), prisún. On the other hand, being a simple orthographical rule it does not provide any help in finding an exact date for a word's appearance in the language, but only in tracing the time of its first written record.

Words can also be grouped semantically. However, the dearth of proper dating may lead us to omit a good deal of words, and there is a danger that the whole exercise may be easily turned into a guessing-game if the proposed classification were to match the pre-conceived expectations. However, let us follow Albert Baugh's classification of French borrowings into English. In this case we will see that the first period comprises the lexis that has to do with the direct contact of French nobility with the residential population. It includes titles, names and other important notions that could have come into use during the first stage of communication, mainly as means to contrast the two cultures in the administrative, legal and religious spheres. The recording of words of the everyday vocabulary can hardly be logically grounded; they seem to have been registered indiscriminately. Thus, we may safely presume that during the first period only the most important and primarily formal words were written down, while many more at the same time were used in the everyday speech.

A greater amount of words fall into the second period. This can possibly be explained not only by the later date of their written records, but also by the changing conditions under which the words made their way

\footnotetext{
${ }^{1}$ For the English language the first period is between 1066-1250 (Baugh 1935: 168).
} 
into Irish in the middle of the fourteenth century. As the French-speaking nobility gradually turned to Irish in everyday speech, they probably supplied any arising deficiencies in their vocabulary through borrowing linguistic items from French which were to fill any semantic gaps in the language itself. But this hypothesis may seem doubtful for the reason that the overall number of loanwords does not seem enough to fill any gap or provide for a compensation of an imperfect command. They must have also kept the words that by that time became widespread among the Irish population. This group has even more correspondences with the borrowings into English, with words, however, quite often very distant in the matter of the first written record. The second period does not include several occasional borrowings from Middle French that were recorded in both English and Irish at the end of the sixteenth century.

\section{Conclusion}

The research hitherto presented is based on a selection of 100 AngloNorman loanwords (Risk 1974: 72-91, 95-96). It involves comparison of the Anglo-Norman French form with its first attestation in Irish and with their Modern Irish forms as different dictionaries suggest (Dineen 1927; Mc Cionnaith 1935; Ó Dónaill 1992; De Bhaldraithe 1998). I tried to date some of the words and where possible adduce the name of the source in which it was first attested (DIL 1990; SnG 1994: 222-225). In most cases, English parallels are provided along with dates of their borrowing (Oxford English Dictionary).

To conclude, let us reiterate that although the Anglo-Norman loanwords do not represent a numerous group, they nevertheless represent a very motivating field of study. They have their own particular phonetic characteristics that distinguished them from those first mediated by English; first and foremost it is the long unstressed last syllable. Semantic peculiarities of this word group are explained by the shortness of the language interaction and by the special status of French as the language of the victorious nobility. The French noblemen influenced the social life of the country by introducing some of their standards - this is what the singled out semantic groups (defined in the second section of the article) prove. Within a period of roughly two centuries these words made their way into the language and became quite productive. Most of them can be found in dictionaries, apart from those that fell out of use together with the concepts which they expressed. However, many of them simply do not exist in the modern colloquial speech and stand on the periphery of the synonymic usage. Another part was fully accepted by the language and these words are no longer per- 
ceived as words of foreign origin. Thus, even the one who knows only "cúpla focal" in Irish is fully aware of an Anglo-Norman borrowing.

Abbreviations

LED - Yartseva 1990.

SnG - McCone, McManus, Ó Háinle, Williams, \& Breatnach 1994

DIL - Quin 1990.

References

Baugh, A. C., 1935: A History of the English Language, New York.

BRUNNER, K., 2003: History of the English Language, Moscow: URSS.

Quin, G., ED., 1990: Dictionary of the Irish Language (Compact Edition), Dublin: Royal Irish Academy.

Dineen, P., 1927 Foclóir Gaedhilge agus Béarla, Dublin: Irish Texts Society.

Kalygin, V. P., \& Korolyov, A. A., 2006: Introduction to Celtic Philology (In Russian: Введение в кельтскую филологию), Moscow: Nauka, (2 $2^{\text {nd }}$ ed.).

Mc Cionnaith, L., 1935: Foclóir Béarla agus Gaedhilge, Baile Átha Cliath.

De Bhaldraithe, T., 1998: English-Irish Dictionary, AN GÚM.

McCone, K., McManus, D., Ó Háinle, C., Williams, N. \& Breatnach, L., eds., 1994: Stair na Gaeilge, Maigh Nuad.

McManus, D., 1983: 'Latin Loan-Words', in: Ériu, 34, 21-71.

Ó Corráin, D., Medieval French Texts (http://www.ucc.ie/celt/frpage.html, accessed 06.02.2009).

Ó DónAILl, N., 1992: Foclóir Gaeilge-Béarla, An Gúm.

Oxford English Dictionary, 1992: OED-2 on CD-ROM, Version 1.02., Oxford: Oxford University Press.

Risk, H., 1970-1971: 'French Loan-Words in Irish (I)', in: Études Celtiques, 12, $585-655$.

Risk, H., 1974: 'French Loan-Words in Irish (II)', in: Études Celtiques, 14, 6798.

SmiRnitskiJ, A. N., 1998: Lectures on the History of the English Language (In Russian: Лекции по истории английского языка), Moscow: Dobrosvet.

YARTSEVA, V. N., ED., 1990: Linguistic Encyclopedic Dictionary (In Russian: Лингвистический энциклопедический словарь), Moscow: Bolshaya Rossijskaja Entsiklopediya. 


\section{Anglo-normanske posuđenice u irskome jeziku}

\section{Sažetak}

U ovom radu proučavaju se i klasificiraju francuske riječi koje je irski posudio u 12.-14. st. Snažan utjecaj Anglo-Normana tijekom ovog razdoblja uzrokovao je aktivno prodiranje francuskog leksika u irski. Većina tih posuđenica ima podudarne riječi u srednjoengleskom koje zamagljuju njihovo podrijetlo. Fonetski oblik riječi pomaže odrediti iz kojeg jezika potječu posuđenice, a omogućava i kronološko određenje riječi.

Značenja posuđenica pokazuju koji su dijelovi života pretrpjeli značajan utjecaj osvajača. Riječi većinom pripadaju specijalnom jeziku i označavaju pojave i predmete netipične ili nove za irsko društvo. Neke značajne i relativno homogene značenjske grupe izdvojene su i objašnjene. Za razliku od engleskog, irski jezik nije dopustio da posuđenice postanu središte već postojećih semantičkih skupova riječi, nego su ostale na rubu i još su uvijek stilski obilježene. Ipak, irski ih je jezik prilagodio sebi i neke su postale običnim dijelom modernog leksika.

U datiranju posuđenica korišteni su dokumenti i književna djela nastali tijekom dva stoljeća nakon normanskog osvajanja, te fonetska analiza koja se najčešće pokazuje najpouzdanijom. Ovdje govorimo o okvirna dva razdoblja posuđivanja i obrazlažemo ih.

Ključne riječi: irski, leksičke posuđenice, posuđenice, francuski, anglo-normanski, normansko osvajanje, semantičke skupine, datiranje, engleski

Key words: Irish, lexical borrowings, borrowings, French, Anglo-Norman, Norman Conquest, semantic groups, dating, English 